\title{
APPLICATION OF THE EVM METHOD AND ITS EXTENSIONS IN THE IMPLEMENTATION OF CONSTRUCTION OBJECTS
}

\author{
Aneta ZIÓŁKOWSKA, Mieczysław POŁOŃSKI \\ Department of Geotechnical Engineering, Faculty of Civil and Environmental Engineering, \\ Warsaw, Poland
}

Received 28 November 2015; accepted 05 February 2016

\begin{abstract}
Surpassing of the planned budget and delivery time is a common feature during the implementation of building investments in Poland. Only a small number of companies use effective methods of project monitoring during investment performance. One of the popular tools used to control projects with regard to cost and time is the earned value method (EVM). There is, however, no detailed guidance how to deploy the method to the specific characteristics and conditions during the execution of building investments. This fact has contributed to this paper, which presents the results of application and adaptation of the earned value method (EVM) and its further extensions in the control of building projects during their execution (with regard to cost and time), prediction of the final duration and costs, and presentation of the effects resulting from calculations. The analyses were performed in terms of the contractor for 5 selected completed and ongoing building projects in Poland.
\end{abstract}

Keywords: building object, project control, cost and delivery time, earned value method, EVM, estimation of time and cost.

\section{Introduction}

The paper concerns the problem of control in the performance of building investments during their implementation with regard to cost and time in relation to the contract execution status. It presents results of calculations based on EVM method and its extension performed on 5 construction projects in Poland. The main purpose of these calculations is to support building investments through efficient control of the project (in terms of time and cost) during its implementation. Overview of international literature signalizes a high demand for project control in each branch of human activity (Latawiec 2012; Czarnigowska, Sobotka 2010; Flyvbjerg et al. 2003). The presented examples of selected investments indicate common surpassing of the planned budget and delivery time. In the case of building projects, due to the large scale of the performance and the specific character of the investment conditions, this surpassing often attains high values.

Moreover, based on experience gained through working in construction companies, search of data for calculation and its collection by authors it was observed that only a small number of companies in Poland use effective methods of project monitoring with regard to the progress of work and costs. Verifications are not conducted according to a well-judged and appropriate methodology and are not a basis to undertake performance decisions.

Many methods supporting project performance have been proposed in the literature (PMI 2008; Kietliński et al. 2007; Jaworski 1999). The methods are often universal and can be adapted to any type of object. One of them is the Earned Value Method (EVM or EV) and its extensions (Vandevoorde, Vanhoucke

Corresponding author:

A. Ziółkowska E-mail: anetaziolkowska@gmail.com 
2006; Webb 2003; Lipke 2003; Cheng, Hoang, 2014). The method is well known (it was developed by the U.S. government in 60 's) and is used for simultaneous control of objects with regard to cost and time. Reports available in international references indicate a large popularity of the method and positive effects of its application (Ziółkowska 2014; Połoński, Komanderek 2011; Sobotka, Czarnigowska 2009; Vandevoorde, Vanhoucke 2006; Vanhoucke, Shtub 2011; Vandevoorde 2013). Studies presented in the literature were applied to implement projects from different disciplines. Only a few reports focus on construction investments and the application of the method to conditions during their performance. Lack of detailed guidance on EVM implementation and lack of application of calculation methods in the monitoring of building objects in Poland have contributed to the presentation of effects resulting from the adaptation and application of the method and its further extensions, based on selected completed and ongoing building objects, and a proposal of a scheme of activities during calculations for further objects in order to increase the effectiveness of control of the projects in terms of cost and time.

The article is divided into four parts: Introduction - where authors present purpose of this article; Calculation methods and objects studied - where are presented and described methods and objects used in the researches; Presentation of the obtained results where are presented the results of calculations; Conclusions - where authors present assessment and conclusions of the researches.

\section{Calculation methods and objects studied}

Traditional methods of controlling construction objects are based on two separate ranges. The first compares the actual progress of works with the basic schedule. The second range includes the financial control of the project, that is the comparison of actual costs with the scheduled costs for the moment of controlling activities. However, such attitude does not indicate the relationship between the progress of works and their cost. This is enabled by the earned value $(E V)$, a third parameter that has been proposed in the EVM method. As a result, effective planning and control of the project, and a three-dimensional assessment of the actual state of the project are possible for the verification time. Because EVM is a statistical method, it also allows predicting the final cost. This is one of the basic and most important advantages of the EVM method.
In Poland complex investigations on the influence of EVM application of the final duration and cost of building projects have not been conducted so far.

The analyses presented in the paper have been subdivided into two groups: basic EVM analysis and a broadened EVM analysis including estimate of cost and final duration.

Prior to the calculations, the following input data had to be determined (Webb 2003):

- $P V(B C W S)$ - planned value (budgeted cost of work scheduled), that is the scheduled cost of the planned work which should be reached at verification time,

- AC (ACWP) - actual cost (actual cost of works performed), that is the actual cost of works performed at verification time,

- EV (BCWP) - earned value (budgeted cost of works performed), that is the planned cost of the works actually performed at verification time. It indicates how many works have been performed and what is their scheduled cost.

The presented data are a function of time, therefore they can be illustrated by curves (Fig. 1). The $P V$ (Planned Value) curve is defined at the beginning of the project and illustrates the planned distribution of costs in time, whereas the remaining curves attain their shapes with current progress of works ( $E V-$ Earned Value curve) and actual costs of project realization ( $A C$ - Actual Cost curve).

Basic EVM analysis. Based on available data on the advancement of works, their planned value $(P V)$,

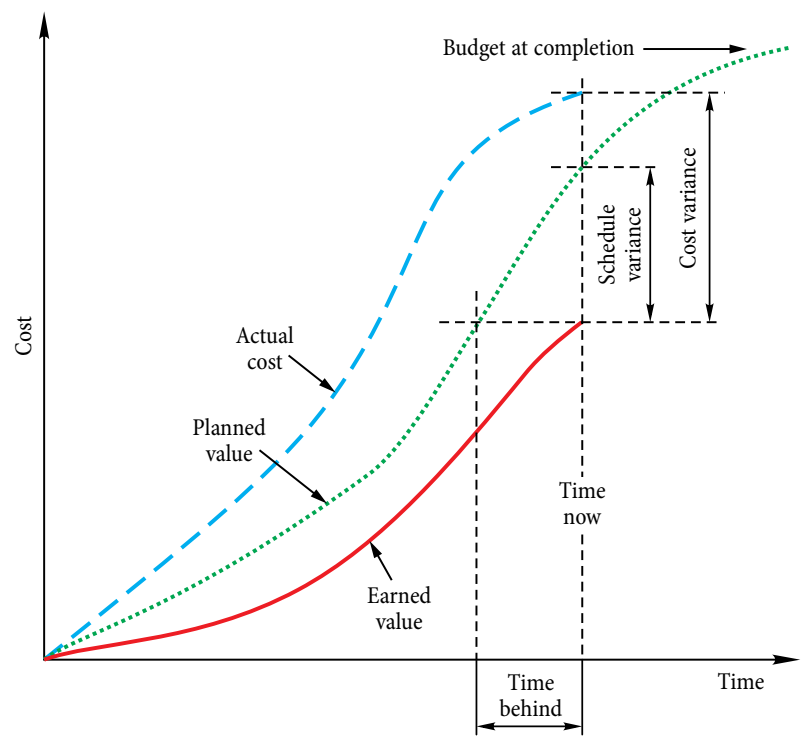

Fig. 1. Earned value graph - AC, EV and PV curves (Roseke 2015) 
actual cost $(A C)$ and earned value $(E V)$, and variances and indexes were determined: cost variance $(C V)$, schedule variance $(S V)$, cost performance index $(C P I)$ and schedule performance index (SPI). These parameters always encompass the interval from beginning of works to the actual date and allow to assess the actual state of the project, that is indicate whether the project is realized according to the schedule, are there any variances and what is their cause. They are determined as follows:

- schedule variance: $S V=E V-P V$,

- schedule performance index: $S P I=\frac{E V}{P V}$,

- cost variance: $C V=E V-A C$,

- cost performance index: $C P I=\frac{E V}{A C}$.

Values of variances $C V, S V<0$, and indexes $C P I$, $S P I<1$ indicate surpassing of scheduled costs and performance delay, respectively. When $C V, S V=0$ and $C P I, S P I=1$, then project performance is according to the planned schedule and budget. In turn, when $C V$, $S V>0$ and $C P I, S P I>1$, then the works are performed below the scheduled budget or faster.
Based on the values obtained from the basic analysis in subsequent verification intervals, a broadened analysis was conducted, which included the estimate of further work progress.

Estimated actual cost. Formulas presented in Table 1 were applied to determine the estimated actual cost in the analysed examples. The analyses were made in two variants: variant I - estimated actual cost was determined for the sum of elements encompassing the entire project, and variant II - estimated actual cost was determined as the sum of estimates for particular elements. The suggested formulas of estimating actual cost were subdivided into three groups, depending on the accepted scenario of work performance: according to the $C P I$ trend (formulas EAC $1,6,8,10,12$ ), according to the $S P I \times C P I$ trend (formulas EAC 3, 7, 11), and according to the plan (formula EAC 5).

Estimated actual duration. The actual duration was estimated based on formulas presented in Table 1. Estimations of actual duration for the objects were determined only in one variant, for the sum of estimates for the entire project. The proposed formulas

Table 1. List of formulas used to estimate the actual cost EAC and duration EAC(t) (personal elaboration)

\begin{tabular}{|c|c|c|c|}
\hline Estimated actual cost EAC & & Estimated actual duration $\mathrm{EAC}(\mathrm{t})$ & \\
\hline Formula & $\begin{array}{l}\text { Formula } \\
\text { index }\end{array}$ & Formula & $\begin{array}{l}\text { Formula } \\
\text { index }\end{array}$ \\
\hline Formulas proposed by Alan Webb (Webb 2003) & & The Planned Value Method (Anbari 2003) & \\
\hline $\mathrm{EAC}=\mathrm{AC}+(\mathrm{BAC}-\mathrm{EV}) / \mathrm{CPI}$ & EAC 1 & $\mathrm{EAC}(\mathrm{t}) \mathrm{PV} 1=\mathrm{SAC}-\mathrm{TV}$ & PV1 \\
\hline $\mathrm{EAC} 1=\mathrm{AC}+(\mathrm{BAC}-\mathrm{EV}) /(0.5 \mathrm{CPI} \times 0.5 \mathrm{SPI})$ & EAC 2 & $\mathrm{EAC}(\mathrm{t}) \mathrm{PV} 2=\mathrm{PD} / \mathrm{SPI}$ & PV2 \\
\hline $\mathrm{EAC} 2=\mathrm{AC}+(\mathrm{BAC}-\mathrm{EV}) / \mathrm{SPI} \times \mathrm{CPI}$ & EAC 3 & $\mathrm{EAC}(\mathrm{t}) \mathrm{PV} 3=\mathrm{PD} / \mathrm{SCI}$ & PV3 \\
\hline $\begin{array}{l}\text { Formulas proposed by Frank T Anbari } \\
\text { (Anbari 2003) }\end{array}$ & & The Earned Duration Method (Jacob, Kane 2004) & \\
\hline $\mathrm{EAC}=\mathrm{AC}+\mathrm{BAC}-\mathrm{EV}$ & EAC 5 & $\begin{array}{l}\mathrm{EAC}(\mathrm{t}) \mathrm{ED} 1=\mathrm{AD}+(\mathrm{PD}-\mathrm{ED}) / 1= \\
\mathrm{PD}+\mathrm{AD}(1-\mathrm{SPI})\end{array}$ & ED1 \\
\hline $\mathrm{EAC} 3=\mathrm{BAC} / \mathrm{CPI}$ & EAC 6 & $\mathrm{EAC}(\mathrm{t}) \mathrm{ED} 2=\mathrm{AD}+(\mathrm{PD}-\mathrm{ED}) / \mathrm{SPI}=\mathrm{PD} / \mathrm{SPI}$ & ED2 \\
\hline Formula proposed by Heinze (Anbari 2003) & & $\begin{array}{l}\mathrm{EAC}(\mathrm{t}) \mathrm{ED} 3=\mathrm{AD}+(\mathrm{PD}-\mathrm{ED}) / \mathrm{SCI}=\mathrm{PD} / \mathrm{SCI}+ \\
\mathrm{AD}(1-1 / \mathrm{CPI})\end{array}$ & ED3 \\
\hline $\mathrm{EAC}=\mathrm{BAC} /(\mathrm{CPI} \times \mathrm{SPI})$ & EAC 7 & $\mathrm{ED}=\mathrm{AD} \times \mathrm{SPI}$ & \\
\hline Department of Energy US (2003) & & The Earned Schedule method (Lipke 2004) & \\
\hline $\mathrm{EAC} 2=\mathrm{AC} / \mathrm{EV} \times \mathrm{BAC}$ & EAC 8 & $\mathrm{EAC}(\mathrm{t}) \mathrm{ES}=\mathrm{AD}+(\mathrm{PD}-\mathrm{ES}) / \mathrm{PF}$ & \\
\hline $\mathrm{EAC} 5=\mathrm{AC}+[1 / \mathrm{CPI}(\mathrm{BAC}-\mathrm{EV})]$ & EAC 10 & $\mathrm{EAC}(\mathrm{t}) \mathrm{ES} 1=\mathrm{AD}+(\mathrm{PD}-\mathrm{ES}) / 1=\mathrm{AD}+(\mathrm{PD}-\mathrm{ES})$ & ES1 \\
\hline Formulas proposed by Athey (Athey 2007) & & $\mathrm{EAC}(\mathrm{t}) \mathrm{ES} 2=\mathrm{AD}+(\mathrm{PD}-\mathrm{ES}) / \mathrm{SPI}(\mathrm{t})$ & ES2 \\
\hline $\mathrm{EAC}=\mathrm{AC}+\mathrm{RB} /(\mathrm{CPI} \times \mathrm{SPI})$ & EAC 11 & $\begin{array}{l}\mathrm{EAC}(\mathrm{t}) \mathrm{ES} 3=\mathrm{AD}+(\mathrm{PD}-\mathrm{ES}) /(\mathrm{CPI} \times \mathrm{SPI}(\mathrm{t}))= \\
\mathrm{AD}+(\mathrm{PD}-\mathrm{ES}) / \mathrm{SCI}(\mathrm{t})\end{array}$ & ES3 \\
\hline \multirow[t]{3}{*}{$\mathrm{EAC}=\mathrm{AC}+\mathrm{RB} / \mathrm{CPI}$} & EAC 12 & Formula proposed by Athey (Athey 2007) & \\
\hline & & ET $1=\mathrm{ST} / \mathrm{SPI}=\mathrm{PD} / \mathrm{SPI}$ & ET1 \\
\hline & & $\mathrm{ET} 2=\mathrm{AT}+(100 \%-\mathrm{PC}) \mathrm{ST}=\mathrm{AT}+(100-\mathrm{PC}) \mathrm{PD}$ & ET2 \\
\hline
\end{tabular}


were subdivided into three groups. Depending in the accepted scenario of work performance: according to the plan (formulas $P V 1, \mathrm{ED} 1, \mathrm{ES1}$ ), according to the $S P I$ trend (formulas $P V 2, \mathrm{ED} 2, \mathrm{ES} 2, \mathrm{ET} 1, \mathrm{ET} 2$ ), according to the SCI trend $(C P I \times S P I)$ (formulas $P V 3$, ED3, ES3).

The calculations were made using the earned value method and its extensions for 5 objects in terms of the contractor. The analysis was made for the following objects:

- object 1 - sanitary sewage system, value of works about 2.5 mil. zloty, performance 20112013, public investor, performed on time, according to budget,

- object 2 - public facility, value of works about 77 mil. zloty, performance 2006-2009, public investor, with surpassed time and cost,

- object 3 - multi-storey building, value of works about 80 mil. zloty, performance 2011-2013, private investor, performed on time, with surpassed cost,

- object 4 - multi-storey building, value of works about 14 mil. zloty, performance 2013 planned completion time 2014, private investor, in progress,

- object 5 - building intended for a hotel, value of works about 14 mil. zloty, performance 20102011, private investor, with surpassed time and cost.

These objects have been selected due to different work scenarios, different types of objects and investors. This fact enabled to conduct calculations and assessments for a group of objects realized in different conditions.

Data required for the analysis were obtained directly from the contractor of the project. None of these objects was controlled during the performance using calculation methods. Only current costs have been compared with the planned expenses for this period at monthly intervals and separately current works progress was monitored in reference to works planned in the construction schedule. Financial schedule did not always coincide with the positions of the construction schedule. Often the construction schedule was more detailed, while positions in financial schedule were more general and resulted from the requirements specified by the investor. Due to these discrepancies, before starting the calculations, obtained data have been analysed, organised and sorted out in order to perform analysis using the EVM method. After adjusting the data, objects had the following number of WBS positions:
- object 1 - only one summing position including direct construction costs and overheads, this was a result of inconsistent cost breakdown in individual months,

- object 2 - 47 cost positions including direct construction costs and overheads,

- object 3 - 46 cost positions including direct construction costs and overheads,

- object 4 - 13 cost positions summing from 108 programme activities and overheads,

- object 5 - 23 cost positions summing from 48 programme activities and overheads.

For four objects the calculations were done in Excel, and for one object the basic analysis was conducted in MS Project and Excel spreadsheets, whereas the broadened analysis - in Excel (object 5). For all object calculations were conducted on a monthly basis.

\section{Presentation of the obtained results}

The calculations were aimed to check if the earned value method and its extensions may simultaneously effectively control the performance of building projects in substantive and financial dimension, and verify whether it is possible to estimate the actual cost and actual duration based on data characterizing the foregoing course of work. Such aim required working out a methodology of object control during work performance, that is indicate the procedures in specific, systematic time intervals from the beginning of the construction till its completion. It included working out procedures of collecting and processing specific data at a required resolution, conducting calculations based on selected formulas and assumed scenarios of further works, and a correct interpretation of their results taking into account the specific character of each investment.

Basic EVM analysis. The basic analysis conducted for real construction objects allowed to verify the validity of EVM application for current control of construction projects during their performance. The calculations confirm that, based on data on completed work, planned value $(P V)$, earned value $(E V)$ and actual cost $(A C)$, the method in the verified interval allows precise determination of works, in which there are deviations of cost and time. As a result, the person responsible for the project can undertake relevant actions to correct the deviations. The method allows to control the project at a random precision level, depending on the requirements of the investment and the person in 
Table 2. Compilation of the most reliable results for estimating the actual cost and actual duration in subdivision of performance time into three parts (personal elaboration)

\begin{tabular}{|c|c|c|c|c|c|c|c|c|}
\hline \multirow{2}{*}{ Object } & \multirow{2}{*}{ Actual cost } & \multirow{2}{*}{$\begin{array}{l}\text { Completion } \\
\text { duration }\end{array}$} & \multicolumn{3}{|c|}{ Estimated actual cost EAC } & \multicolumn{3}{|c|}{ Estimated actual duration EAC(t) } \\
\hline & & & $0-1 / 3$ & $1 / 3-2 / 3$ & $2 / 3-3 / 3$ & $0-1 / 3$ & $1 / 3-2 / 3$ & $2 / 3-3 / 3$ \\
\hline 1 & $\begin{array}{l}\text { According to } \\
\text { the plan }\end{array}$ & $\begin{array}{l}\text { According to } \\
\text { the plan }\end{array}$ & & EAC 5 & EAC 5 & $\begin{array}{c}\text { ET2, ES1 } \\
(\mathrm{PV} 1, \mathrm{ED} 1)\end{array}$ & \begin{tabular}{|c|} 
ES1, PV1, \\
PV2, ED1, \\
ED2, ES2, ET1
\end{tabular} & $\begin{array}{l}\text { PV1, PV2, } \\
\text { ED1, ED2, } \\
\text { ET1 }\end{array}$ \\
\hline 2 & Higher & Longer & EAC 5 & $\begin{array}{c}\text { EAC } 1,6,8 \\
10,12\end{array}$ & $\begin{array}{c}\text { EAC } 1,6,8, \\
10,12 \\
(\text { EAC } 5)\end{array}$ & ET2 (ES3) & PV3 & $\mathrm{ES} 1, \mathrm{ES} 2, \mathrm{ES} 3$ \\
\hline 3 & Higher & $\begin{array}{l}\text { According to } \\
\text { the plan }\end{array}$ & EAC 5 & EAC 7 & EAC 7 & $\mathrm{ES} 1,(\mathrm{PV} 1)$ & ES1 & $\begin{array}{l}\text { ES1 (PV1, } \\
\text { ED1) }\end{array}$ \\
\hline 4 & - & Longer & & & & & & \\
\hline 5 & Higher & Longer & $\begin{array}{c}\text { EAC } 1,6,8 \\
10,12\end{array}$ & $\begin{array}{c}\text { EAC } 1,6,8 \\
10,12\end{array}$ & $\begin{array}{c}\text { EAC } 1,6,8, \\
10,12\end{array}$ & ET2 & ES1 & ES1 \\
\hline
\end{tabular}

Legend:

\begin{tabular}{c}
\hline BAC - according to the plan \\
\hline CPI - according to CPI trend \\
\hline CPI $\times$ SPI - according to CPI and SPI trends \\
SPI - according to SPI trend
\end{tabular}

ET2 - according to ET2

charge. The most important elements influencing the correctness of the conducted analyses include precision, timeliness and regularity in data collection, and consequence in maintaining the earlier planned methodology of data collection and processing, adjusted to the specific character of a particular object. Analyses conducted in this report in many cases indicate large differences in the course of $C P I$ and SPI indexes, which often result from inaccuracies of the actual value of one data used in the calculations; in many cases this refers to the inaccuracy of real costs.

Estimated actual cost and actual duration. Based on input data and parameters determined in the basic analysis, further analyses were conducted; they were aimed at verifying whether formulas available for building objects allow to estimate the actual cost and actual duration, and how precise are these estimates depending on work advancement. Table 2 shows a compilation with the most reliable results for particular objects with regard to actual cost and actual duration, subdivided into three parts. According to the explanations, the shading refers to particular work scenarios. The most reliable results are those that are closest to the final values.

After taking into considerations the remarks and solutions presented in the Ph.D. thesis (Ziółkowska 2015) with regard to the preparation of input data and methods of data collection and processing, the conducted calculations allow to conclude that a reliable and on-going project monitoring is possible during its performance with regard to cost and duration based on selected methods and formulas. The calculations indicate that estimates are very sensitive to input data and reflect every deviation from the schedule during the performance (larger deviation of project from schedule results in a higher estimate, and larger variations between the reports result in larger deviations on the estimate curve).

The calculations confirm the validity of applying selected formulas, on which the actual cost was estimated, assuming particular scenarios of the remaining work. For objects performed on schedule, the estimate concordant with the schedule is proven correct. In the case of deviations during the performance, both with regard to cost and duration, one of the scenarios of work performance should be applied, depending on which difference is larger: according to the actual CPI trend or according to the values of $S P I \times C P I$. For an object realized according to schedule and over budget, the estimate should follow the actual trend of SPI $\times$ CPI. The correctness of the proposed solutions should be verified on a larger number of objects.

With regard to the estimated duration, the research has confirmed literature data (referring mainly, 
however, to objects that were not construction objects) that in most cases the most reliable results after estimate stabilization are obtained by ES formulas (Vandevoorde, Vanhoucke 2006). For an object performed according to schedule, the most reliable estimates are obtained by on-schedule formulas and ET1 estimate. In the case of deviations in the performance with regard to duration and cost, the most reliable are ES (mainly ES1) and ET2 estimates.

\section{Conclusions}

Review of available literature, experience and knowledge gained during the realisation of construction projects in Poland and the results obtained from the performed calculations allow to draw the following conclusions:

- The basic EVM analysis identifies deviations of the project in terms of cost and duration of construction investments. Correctness of the

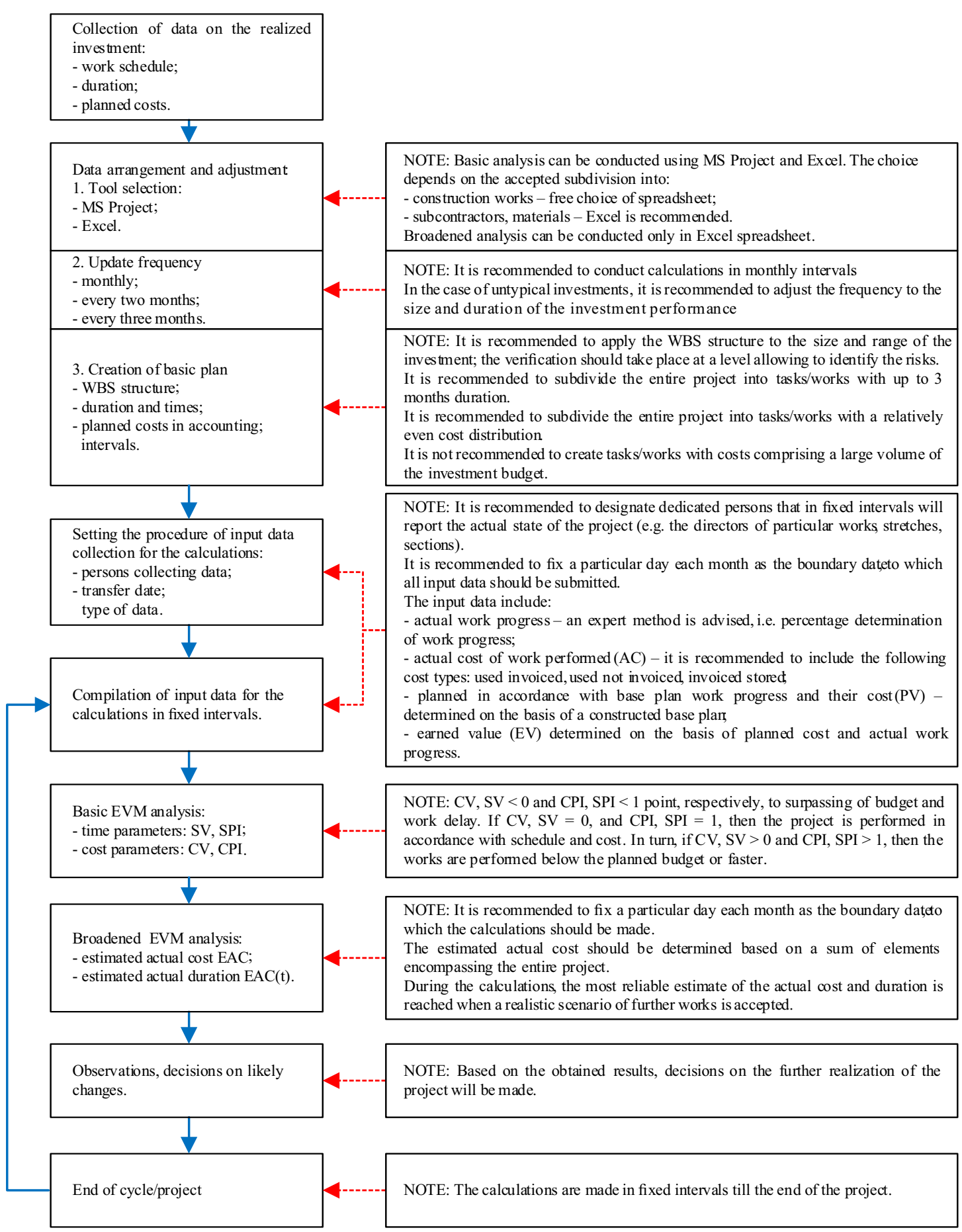

Fig. 2. Scheme of actions undertaken during the calculations with application of the EVM method and its further extensions 
obtained results is determined by the reliability of the collected data,

- Detailed methodology of collecting and compiling data for EVM calculations should be developed at the beginning of the project and include the contractor's capabilities and the specifics of the project,

- The basic EVM analysis can be performed at any level of detail. The WBS structure should be adapted to the specifics of the project, the scale, size and purpose for which it is prepared. Planning of an individual task with an assigned high cost (covering a significant part of the entire project costs) should be avoided,

- Reliability of the schedule is essential for the progress of work. Annexing of the contract has impact on controlling of the project in terms of time and/or cost, although does not affect the accuracy of forecasting the actual cost and duration,

- The performed calculations have shown that the estimated cost and duration are highly sensitive to data used in the analysis. It is recommended to take into consideration three types of costs: used and invoiced, used and not invoiced, invoiced and stored,

- The estimated actual cost should be calculated based on the sum of elements encompassing the entire project,

- To obtain the most reliable estimated actual cost and duration, a realistic scenario of further works has to be assumed, in accordance with the actual progress of the project,

- The estimated actual cost and duration are not reliable in the first period of the project; they stabilize in the second period, in which, depending on the scenario assumed for further works, they estimate actual values with high accuracy.

When conducting calculations in the proposed method, it should be remembered that the estimate points only to the direction, in which the work proceeds, based on the actual performance. Change of work rate, efficiency, etc., may change the indexes used to determine the estimate, and the estimate itself. Therefore, good knowledge of the realities in the investment, the applied technology and work organization, and the way of effective application of the EVM method should enable correct monitoring of the object during its performance, draw correct conclusions, determine reliable estimates and undertake effective decisions.

The presented results are only an introduction to analyses using EVM and its extensions during the realization of construction objects in conditions that at present prevail in Poland. These are pilot investigations, which signalize issues that should be verified and recognized in further studies. They have also allowed to indicate how the EVM method should be adjusted to construction practice. The gained experience has allowed to construct a scheme (Fig. 2) with the subsequent steps that should be undertaken during the calculations.

\section{References}

Anbari, F. 2003. Earned value method and extensions, Project Manage Journal 34(4): 12-23.

Athey, K. 2007. EVM - current solution and roadmap to adoption [online], [cited 23 March 2013]. Available from Internet: http://media.hypersites.com/clients/1105/filemanager/ QPMEVMWhitepaper.pdf

Cheng, M.-Y.; Hoang, N.-D. 2014. Interval estimation of construction cost at completion using least squares support vector machine, Journal of Civil Engineering and Management, 20: 1-14. http://dx.doi.org/10.3846/13923730.2013.801891

Czarnigowska, A.; Sobotka, A. 2010. Przewidywalność czasu trwania budowy: publiczne przedsięwzięcia drogowe, Technical Transactions 107(2): 23-34.

Department of Energy, USA. 2003. EVM Tutorials, Module 1-8 [online], [cited 17 July 2003]. Available from Internet: http://energy.gov/management/office-management/operational-management/project-management/earned-valuemanagement Flyvbjerg, B.; Bruzelius, N.; Rothengatter, W. 2003. Megaprojects and risk. An anatomy of ambition. UK: Cambridge University Press. http://dx.doi.org/10.1017/CBO9781107050891

Jacob, D.; Kane, M. 2004. Forecasting schedule completion using earned value metrics revisited, The Measurable News Summer: 11-17.

Jaworski, K. M. 1999. Metodologia projektowania realizacji budowy. Warszawa: Wydawnictwo Naukowe PWN.

Kietliński, W.; Janowska, J.; Woźniak, C. 2007. Proces inwestycyjny w budownictwie. Warszawa: Oficyna Wydawnicza Politechniki Warszawskiej.

Latawiec, T. 2012. Kryteria wyboru oferty najkorzystniejszej ekonomicznie [online]. Inżynier budownictwa [cited 23 March 2013]. Available from Internet: http://www.inzynierbudownictwa.pl

Lipke, W. 2003. Schedule is different. The Measurable News March: 31-34.

Lipke, W. 2004. Connecting earned value to the schedule, The Measurable News Winter: 6-16.

Project Management Institute (PMI). 2008. A guide to the Project management Body of Knowledge (PMBOK Guide). PMI, United States. 
Połoński, M.; Komanderek, P. 2011. Bieżąca kontrola kosztów realizacji obiektu budowlanego metodą Earned Value, $M e$ tody ilościowe w badaniach ekonomicznych XII/2: 279-290.

Roseke, B. 2015. Use earned value management to move projects forward [online]. Project Engineer [cited 18 February 2015]. Available from Internet: http://www.projectengineer.net/ use-earned-value-management-to-move-projects-forward/

Sobotka, A.; Czarnigowska, A. 2009. Sterowanie realizacją przedsięwzięcia budowlanego z wykorzystaniem metod planowania i kontroli przebiegu robót, in VI Science and Technology Conference „Issues of Preparation and Implementation of Construction Projects - Workshops for Building Engineers", 19-21 October 2009, Pulawy, Poland.

Vandevoorde, S.; Vanhoucke, M. 2006. A comparison of different project duration forecasting methods using earned value metrics, International Journal of Project Management 24(4): 289-302. http://dx.doi.org/10.1016/j.ijproman.2005.10.004
Vanhoucke, M.; Shtub, A. 2011. Adding value to earned value analysis in 22nd Annual Conference of the Production and Operations Management Society, April 29 - May 2 2011, Reno, Nevada, USA.

Vandevoorde, S. 2013. ES-05: time forecasting using earned schedule [online], [cited 4 December 2013]. The European Experience. Available from internet:: http://www.evm-europe.eu/

Webb, A. 2003. Using earned value: a project manager's guide. Hampshire: Gower Pub Co.

Ziółkowska, A. 2014. EV with duration forecasting. Case study, Technical Transactions 2B(6): 299-307.

Ziółkowska, A. 2015. Supporting the realization of a construction project using the earned value method: Doctoral thesis. SGGW, Warsaw.

Aneta ZIÓŁKOWSKA is a civil engineer with experience in project management. She did PhD degree at Warsaw University of Life Sciences at the Faculty of Civil Engineering in April 2015 in the specialization of organization and management in the construction industry. She has over 5 years of experience working at construction projects in Poland. At the moment she is working in the field of Project and Cost Management in Construction in New Zealand.

Mieczysław POŁOŃSKI. Since 2000 he is the professor in Warsaw University of Life Sciences in Poland and currently holds the position of head Technology and Engineering Management Division in Faculty of Civil and Environmental Engineering. Fields of his research are: schedule and planning of engineering works, investment process, progress work monitoring and cost engineering. For a few years he is especially interested in risk analysis as well as application of time and cost buffers in construction schedule. Other area of his current interests is prediction of the final duration and costs of construction project. 